\title{
The IMF and the New Fiscalism: was there a U-turn?*
}

\author{
Brett Fiebiger \\ University of Ottawa, Canada \\ Marc Lavoie** \\ University of Ottawa, Canada and University of Paris 13 (CEPN), France
}

\begin{abstract}
In late 2008 a consensus was reached amongst global policymakers that fiscal stimulus was required to counteract the effects of the Great Recession, a view dubbed as the New Fiscalism. Pragmatism triumphed over the stipulations of the New Consensus Macroeconomics, which viewed discretionary fiscal actions as an irrelevant tool of counter-cyclical macroeconomic policy (if not altogether detrimental). The partial re-embrace of Keynes was however relatively short-lived, lasting only until early 2010 when fiscal consolidation came to the forefront again, although the merits of fiscal austerity were questioned when economic recovery did not really materialize in 2012. This paper traces the ups and downs of the debate over the New Fiscalism, especially at the International Monetary Fund, by analysing IMF documents and G20 communiqués. Using fiscal policy as a means to exit the crisis remains contentious even amidst recognition of secular stagnation.
\end{abstract}

Keywords: New Fiscalism, fiscal consolidation, expansionary austerity, functional finance, sound finance

JEL codes: $E 62, H 6$

\section{INTRODUCTION}

'[T]he idea that austerity measures could trigger stagnation is incorrect.' Jean-Claude Trichet (2010)

In the 1990s the thoughts of mainstream economists on macroeconomics became codified in the New Neoclassical Synthesis or New Consensus Macroeconomics (NCM). Many came to believe that the mix of an inflation-targeting regime and an assortment of sophisticated financial innovations had permanently dampened the perpetuations of the business cycle à la the Great Moderation (Bernanke 2004; Cecchetti et al. 2006). The execution of macro policy was seen as straightforward. The federal government should strictly adhere to the principles of sound finance, which in practice either meant a balanced budget or developing transparent fiscal rules to show a medium-term commitment to stabilizing

* Very preliminary versions of this paper were presented at the annual conferences of the Eastern Economic Association in 2013 and 2014. The research benefited from a grant provided by the Institute for New Economic Thinking (INET), which in particular financed the post-doctoral position of Brett Fiebiger at the University of Ottawa. We are grateful for the comments provided by the two referees of the journal.

** Corresponding author: Email: Marc.Lavoie@uottawa.ca.

Received 13 June 2016, accepted 3 January 2017 
the public gross debt level at some arbitrary ratio relative to output. Monetary policy was framed in reference to the pre-Keynesian Wicksellian natural rate of interest. The central bank had one policy instrument (short-term interest rate) and one overriding policy goal (price stability, through inflation targeting).

Associated with the concept of the natural rate of interest, the NCM also incorporated the notion of a natural rate of unemployment. In more practical terms, this meant that economies were subjected to a non-accelerating inflation rate of unemployment - the NAIRU - with ties to the concept of potential output. As pointed out recently by Janet Yellen (2016: 2), it was then believed that changes in aggregate demand would have no 'appreciable, persistent effect on aggregate supply'. This meant that potential output, despite a negative demand shock (for instance monetary tightening orchestrated by the central bank to reduce inflation), would quickly come back to its previously forecast level. It also meant that the NAIRU was fully determined by supply-side elements. With aggregate demand being perceived as 'explaining shorter-term variations around an almost exogenous supply-determined longer-run trend' (ibid.: 2), this implied that the NAIRU could only be reduced through the so-called structural reforms of the labour market, a euphemism for more flexible labour markets, wage repression and a reduction in social protection.

When global finance collapsed in 2008, so did the theoretical premises of the NCM. The initial intellectual response from neoliberal orthodoxy was to portray the financial crisis as an unpredictable perfect storm (Blanchard 2008). A twofold crisis strategy was advised: (i) support the financial sector; and (ii) implement a large yet short-term dose of fiscal stimulus. Policymakers across the world broadly embraced that stratagem as a matter of pragmatism. The newfound attitude in the corridors of officialdom to finding a constructive role for discretionary fiscal policy received the moniker of New Fiscalism by Seccareccia $(2011 / 2012 ; 2012)$. It was a hybrid position that neither fully endorsed the principles of sound finance nor the principles of Lerner's (1943) functional finance.

It may be worthwhile to briefly recall Lerner's position. His main claim was that a government budget surplus or deficit, in and of itself, is neither good nor bad. The goal of fiscal policy ought to be the achievement of the proper level of employment, one that can provide for full employment, without inflation. As Lerner (1943: 39) puts it, 'the central idea is that government fiscal policy, its spending and taxing, its borrowing and repayment of loans, its issue of new money and its withdrawal of money, shall all be undertaken with an eye only to the results of these actions on the economy and not to any established traditional doctrine about what is sound or unsound' (emphasis in original). Lerner (ibid.) further argued that there is no financial constraint on a government backed by a central bank. And Lerner's third claim is that even if the government engages in substantial deficit-spending as a counter-cyclical measure, the public-debt-to-GDP ratio will eventually converge to a finite value. An extension of Lerner's functional finance and its rejection of the concept of sound finance or good debt could be the arbitrariness of the Golden Rule, the balanced-budget rule exempting public investment, for, as Wynne Godley (2005) used to say: 'There exists no relevant difference between, say, capital expenditure on school building and current expenditure on teachers. Both are equally necessary for education and both absorb resources (pound for pound) to roughly the same extent'.

By contrast, in its recent advice the IMF has tended to favour stimulus through public investment only. As to the New Fiscalism from late 2008 to early 2010, stimulus programs were acceptable to counteract cyclical downturns but only for countries deemed to have fiscal space, a phrase oft used yet never precisely defined. Furthermore, fiscal consolidation had to be pursued as soon as possible so as to protect the fiscal space needed for future crises. These amendments to the principles of sound finance were justified by prominent New Keynesians on the ground that the central bank's target interest rates were at 
or close to the nominal zero lower bound, so that central banks were unable to bring real interest rates to a level negative enough to be compatible with potential output or the natural rate of unemployment - an argument presented by Paul Krugman as a liquidity trap, but which echoed the explanation proposed by some old Keynesians more than half a century earlier (Patinkin 1948). ${ }^{1}$

The purpose of the present paper is to examine the evolution of views professed by the International Monetary Fund (IMF) with regards to fiscal policy. ${ }^{2}$ Going over the various IMF World Economic Outlooks and other documents, can it be said that there was a complete U-turn in the IMF's position on fiscal policy? Our analysis shows that there was not a complete 180-degree turnabout in 2008 - which would have been a move from full austerity to all-out stimulus - but rather something like a 150-degree change in the views held by the IMF, with a prudent move to advocating fiscal stimulus. Similarly, the retrenchment away from fiscal stimulus policies that was observed in 2010 was not a full obliteration of its previous position, despite its support of policies based on socalled expansionary fiscal consolidation in the eurozone. Further, there was another cautious reversal of policy advice from around the beginning of 2013, first when the IMF realized that austerity policies were not providing the expected positive effects and that the eurozone was in danger of implosion, and then when the IMF acknowledged that they had underestimated the value of fiscal multipliers in recessions (Blanchard/Leigh 2013). Finally, in view of tepid growth and with Summers (2013) reviving interest in another old Keynesian concept - that of secular stagnation (Hansen 1939) - there were tentative steps from around 2014 towards a New Fiscalism: Mark II. The main idea is that countries with sufficient fiscal space could again contemplate debt-financed fiscal stimulus, and with full accommodation by monetary policy, so long as the expenditures were targeted to programmes with high fiscal multipliers and raised potential growth in the medium-run.

In the following pages we collect evidence on these various turnabouts, starting in Section 2 with a brief review of the state of thinking on macro issues amongst official bodies before the Great Recession. Section 3 documents the partial embrace of Keynes and Keynesian expansionary macro policies in the New Fiscalism. In Section 4 attention is given to the manifest retrenchment away from the New Fiscalism, which culminated on the academic front, as shown in Section 5, with the proof by Reinhart/Rogoff (2010) that high public-debt ratios were detrimental to economic growth, thus providing intellectual ammunition to those who wish to go back to austerity policies. Section 6 documents the other partial U-turn of the IMF, when the European Monetary Union was brought back from the brink of imminent break-up and, even more so, once the region succumbed to a second recession. This was followed, as discussed in Section 7, by a tilt further towards a

1. Keynes never used the term liquidity trap. In chapter 15 Keynes (1936) mentioned the possibility that liquidity preference could become virtually absolute at some low rate of interest (due to market expectations of prospective capital losses on long-term bonds) but knew no example of it. By contrast the New Keynesian version of the liquidity trap refers to the nominal bound limit on short-term interest rates, which causes problems in the New Keynesian consumption models such as Eggertsson/Krugman (2012), as a large shock can make the natural rate needed to induce intertemporal consumption equal to a negative value. In chapter 17, Keynes (1936) rejected the utility of the Wicksellian natural rate and would likely have objected to positions built around the permanent income hypothesis (which supposes a high level of rationality and foresight).

2. There is a paper by Vernengo/Ford (2014) that covers some of the same ground. Their conclusion is that the 2008 crisis prompted only some cautious change in the views being entertained at the IMF. 
Keynesian macro policy orientation arising out of concerns that secular stagnation may be the new normal. ${ }^{3}$

\section{THE STATE OF THINKING IN OFFICIALDOM PRIOR TO THE GREAT RECESSION}

This chapter finds that, in important ways, the global economy has recently displayed greater stability than observed even in the 1960 s... The durability of expansions largely reflects sources that are likely to prove persistent, including improvements in the conduct of monetary and fiscal policy, as well as in broader institutional quality. (IMF WEO September 2007: 171)

The old Keynesian paradigm that dominated the mainstream economics profession from the 1940s to the 1970s identified a constructive role for fiscal policy in demand management. By contrast the version of mainstream economics that took its place viewed fiscal policy as a hindrance. There was acceptance of Ricardian equivalence, which meant that the expansionary impact of fiscal deficits would be nullified by the saving decisions of agents, and there was the firmly held belief that an independent central bank was nearly omnipotent in its ability to affect output and employment levels in the short run and hence to fully control wage and price inflation (Krugman 1997). In practice it was the European Central Bank (ECB) that most rigorously pursued its mandate of price stability and in the process helped make the eurozone the sick man of the world during the 2000s global expansion. Germany was in turn the sick man of Europe, with notorious reliance on net exports and stagnation in domestic demand (Bibow 2013). On the other side of the Atlantic there was much optimism about a Great Moderation and the apparent merits of the laissez-faire invisible hand approach to financial sector regulation (Bernanke 2004; 2007). The state of orthodox thinking on macro was fêted as complete such that the 'central problem of depression prevention has been solved, for all practical purposes, and has in fact been solved for many decades' (Lucas 2003: 1).

One concern was the widening in global current-account imbalances during the 2000s upswing. The IMF came to the view that coordinated policy action was required to facilitate an adjustment in the US current account from deficits in excess of 5 per cent of gross domestic product (GDP) during 2004 and 2005, down to levels of around 2-3 per cent, which the Fund considered could be indefinitely sustained (IMF 2007). Subsequently, in early 2006 the IMF began a process of multilateral consultations with the major players (the United States, the euro area, Japan, Saudi Arabia, and in particular China). Within a year of the first multilateral talks the Fund all but declared mission accomplished in its April 2007 edition of the World Economic Outlook (WEO): '[this WEO] sees global economic risks as having declined since our last issue in September 2006 ... there is less reason to worry about the global economy' (IMF WEO April 2007: xii). That was followed by a similarly sanguine endorsement of the Great Moderation theme in the September 2007 WEO.

The G20 grouping was launched in 1999 as a forum for multilateral discussions that was more representative than the G7 or G8 groupings because it included major emerging economies. During the presidency of George Bush Jr the focus was the war on terror. Some attention was given to economic issues; notably, the US budget deficit. The November 2004 Berlin communiqué of G20 finance ministers and central bank governors (FMCBG) underscored 'the importance of medium-term fiscal consolidation in

3. On secular stagnation, see the special issue of EJEEP edited by Gechert et al. (2016). 
the United States' (G20 FMCBG November 2004). At the same meeting the G20 Accord for Sustained Growth Stability, Competition and Empowerment also underlined the importance to macro stability of price stability and fiscal discipline, which are the two key pillars of the NCM. Medium-term fiscal consolidation in the US was again emphasized as essential to securing a soft landing for global imbalances in the November 2007 communiqué of the G20 FMCBG held near Cape Town:

We also agreed that an orderly unwinding of global imbalances, while sustaining global growth, is a shared responsibility involving: steps to boost national saving in the United States, including continued fiscal consolidation ... We considered the macroeconomic implications of creating fiscal space ... and highlighted the importance of a sound medium- to long-term fiscal framework in creating and maintaining fiscal space. (G20 FMCBG November 2007)

The concept of fiscal space often appears in official communiqués and orthodox literature. It is a nebulous concept as it is not made apparent why Japan with high levels of public debt has fiscal space while countries in the eurozone periphery did not. What matters here is that prior to the Great Recession most in officialdom were expecting a smooth and gradual unwinding of global imbalances, with only modest spillovers from the slowdown in US housing markets.

\section{PRAGMATISM FORCES THE NEW FISCALISM}

Unease about the size and dispersal of losses on US residential mortgage-backed securities began to surface in mid 2007. By early 2008, and with the takeover of US investment bank Bear Stearns a sign of things to come, the IMF was only just starting to realize that the turmoil in financial markets was not contained but was instead gathering momentum. In its April 2008 edition of the WEO the Fund warned of a 'hard-to-defeat financial decelerator' (IMF WEO April 2008: xi) and predicted an imminent recession for the United States. It also laid out the key aspects of the New Fiscalism, according to which fiscal stimulus ought to be 'timely, temporary and targeted', as had been stated by the managing director of the IMF - Dominique Strauss-Kahn - as early as January 2008 (as recalled by Cline et al. 2010: 110).

Fiscal policy can play a useful stabilizing role ... although it should not jeopardize efforts aimed at consolidating fiscal positions over the medium term. In the first place, there are automatic stabilizers that should provide timely fiscal support ... In addition, there may be justification for additional discretionary stimulus in some countries ... but any such stimulus must be timely, well targeted, and quickly unwound. (IMF WEO April 2008: xvi, emphasis added)

By the time the October 2008 WEO was released, the US Treasury had placed the nation's two largest mortgage lenders under conservatorship and the global financial system was in a state of cardiac arrest following the sudden bankruptcy of US investment bank Lehman Brothers. Under the stewardship of new Chief Economist, Oliver Blanchard, the IMF repeated its newfound support for using fiscal policy to combat recessionary forces (IMF WEO October 2008: xvii). Equivalent views were expressed in the November 2008 G20 FMCBG communiqué at the Sao Paulo meeting. At the April 2009 London meeting, G20 leaders backed the 'unprecedented and concerted fiscal expansion, which will save or create millions of jobs' (G20 Leaders April 2009) while also confirming that the principles of sound finance would eventually return: 'We are resolved to ensure longterm fiscal sustainability and price stability and will put in place credible exit strategies' (ibid.). Over time the accent that global policymakers placed on fiscal expansion relative 
to fiscal consolidation shifted back to the former, but not during 2009, which saw the largest year-over-year fall in global economic output since the Great Depression.

An IMF Staff Position Note from Spilimbergo et al. (2008) provided the official guidelines on optimal fiscal packages for the crisis. Amongst the advice were allowing the automatic stabilizers to function, temporarily increasing employment in the public sector (but not public sector wages), temporarily lowering value added taxes and increasing the State's role in financial intermediation. Spilimbergo et al. (ibid.) stressed the importance of designing reversible stimulus packages, though their specificity was on building a 'collective international effort' to reflate in a context where '[s]ome countries have questioned the need for fiscal action and whether it can be effective' (ibid.: 12, emphasis in original). For seasoned observers, the Fund's calls for a synchronized fiscal expansion were out of character. Its track record after the purging of Keynesian influence in the early 1980s was dogmatic imposition of macro austerity as a precondition for receiving official assistance in spite of the deflationary consequences (Stiglitz 2002). Regrettably, and reprehensibly, in early 2010 when the eurozone's sovereign debt crisis erupted the IMF had no policy answers which resembled Keynesianism in any shape or form. Only from around 2013 did the Fund start to query the strong anti-Keynesianism of European officialdom. Nonetheless, for our narrative here, from the latter half of 2008 through all of 2009 the New Fiscalism was ascendant. Heterodox economists hailed the return of fiscal policy as a return of sensibilities (Arestis/Sawyer 2010).

Officials let the automatic stabilizers do their work and were opening the public sector's purse while promising to provide the details on an eventual return to sound finance at a later, as yet undecided, point in time. Along these lines the G20 FMCBG agreed at the September 2009 London meeting on the 'need for a transparent and credible process for withdrawing our extraordinary fiscal, monetary and financial sector support as recovery becomes firmly secured' (G20 FMCBG September 2009). G20 leaders likewise claimed at the September 2009 Pittsburgh meeting that '[w]e will avoid any premature withdrawal of stimulus' (G20 Leaders September 2009). That they also communicated 'the rise in private saving now underway will, in time, need to be augmented by a rise in public saving' (ibid., emphasis added) may offer an insight into why world leaders had difficulty in choosing the policies needed to sustain global economic growth. Unless the relevant countries were expected to experience growth in net exports it is illogical to suppose the private sector and public sector can both augment saving as a matter of sectoral financial balance accounting (Godley/Cripps 1983: 284). Unfortunately it is not uncommon for official bodies to strongly recommend that the private sector and public sector both simultaneously increase saving, consolidate and deleverage from debt.

Returning to the unfamiliar role of the Fund as an advocate of active demand management, the IMF urged in its November 2008 WEO Update for further policymaking action on the fiscal front, pointing to the limitations in the capacity of monetary policy to promote recovery that we underlined in the introduction:

There is a clear need for additional macroeconomic policy stimulus ... However, monetary policy may not be enough because monetary easing may be less effective in the face of difficult financial conditions and deleveraging. Also, in some cases room for further easing is limited as policy rates are already close to the zero bound. These are conditions where broad-based fiscal stimulus is likely to be warranted. (IMF WEO Update November 2008: 3-4, emphasis added)

The themes of private debt deleveraging and constraints on monetary policy at the nominal zero lower bound received attention from Eggertsson/Krugman (2012) and other New Keynesians. As we will see in Section 6 and Section 7, the old Keynesian concepts of the liquidity trap and secular stagnation surfaced as a dividing point between 
New Keynesians in the IMF and voices in European officialdom. Whatever criticism the Fund justifiably deserves, a shift from neoliberalism back towards Keynesianism did occur, at least during the acute phases of the crisis. For a while the principles of sound finance were not forgotten but certainly de-prioritized:

While governments have acted to provide substantial stimulus in 2009, it is now apparent that the effort will need to be at least sustained, if not increased, in 2010, and countries with fiscal room should stand ready to introduce new stimulus measures as needed to support the recovery. As far as possible, this should be a joint effort ... (IMF WEO April 2009: xv, emphasis added)

The IMF was even bolder in its next edition of the WEO: 'Notwithstanding already large deficits and rising public debt in many countries, fiscal stimulus needs to be sustained until the recovery is on a firmer footing and may even need to be amplified or extended beyond current plans if downside risks to growth materialize' (IMF WEO October 2009: xi, emphasis added). Having been wrong about downside risks before the Great Recession, and with fiscal space still seemingly available, the Fund did not want to make a broad call for belt-tightening until there were signs that the crisis was abating. Within 6 months a few green shoots of recovery had sprouted. That the recovery was still uncertain can be gleaned from the April 2010 G20 FMCBG communiqué at their meeting in Washington: 'Countries who have the capacity should expand domestic sources of growth. This should help cushion a decline in demand from countries that should boost savings and reduce fiscal deficits' (G20 FMCBG April 2010). In a short period of time the word should reduce fiscal deficits became must for countries in the eurozone periphery.

\section{A FRACTURING OF THE POLITICAL WILL TO RECOVER}

There is only one course of action: all eurozone members must return to adherence to the stability and growth pact as rapidly as possible. (Schäuble 2010)

During 2008 and 2009 the main component of the crisis response in advanced economies was extensive public sector funding support of the financial sector. ${ }^{4}$ With financial markets brought back from the precipice of self-annihilation and the real economy showing signs of stabilization it was hoped that a broad-based recovery would materialize in 2010. Strains, however, emerged in bond markets for member governments in the eurozone periphery. Initially, the country that came under funding pressure was Greece, though as the crisis spread it eventually engulfed the grouping known as GIIPS (that is, Greece, Ireland, Italy, Portugal and Spain).

In March 2010 the task of drafting reforms for the eurozone was assigned to a task force under the supervision of the President of the European Council. The Herman van Rompuy task force delivered its final report in October 2010. Many of the reforms later adopted were canvassed in the European Commission's (2010) blueprint that was released in May (for example, the European Semester, integrating the objective of sound finance into national law, proposes to subject members with public-debt-toGDP ratios above 60 per cent to excessive deficit procedures). From late 2010 the

4. The IMF (2009: 39) estimated collective public support of the financial sector for the US, eurozone and the UK at $\$ 8.95$ trillion. For the US it was $\$ 4.66$ trillion, a huge amount compared to the modest fiscal stimulus packages of $\$ 168$ billion and $\$ 787$ billion ratified, respectively, by the US Congress in February 2008 and February 2009. 
eurozone adopted one reform after another to give the Stability and Growth Pact more teeth and to obtain a stricter regime of fiscal governance. To the extent that the eurozone had hitherto embraced the New Fiscalism, it was now over.

The immediate task that eurozone policymakers chose to undertake was to accelerate the pace of fiscal consolidation. That stratagem was claimed to be pro-growth. Even though Germany had the fiscal space to do otherwise, and benefited from the investor flight from the eurozone periphery lowering yields on safe German public debt, it also undertook rapid fiscal consolidation in 2011. The country was obligated to do so under the debt-brake provisions that were adopted into the German constitution in 2009. The logic of expansionary austerity included the usual claim from neoliberal orthodoxy that benefits would occur from decreasing public sector crowding-out. ${ }^{5}$ Additionally, by instigating immediate spending cuts and/or increasing tax revenues as well as announcing steps to further reduce deficits in the medium term, it was thought that reaffirming commitment to sound finance would calm rational financial markets and lower risk premiums on sovereign bonds. In practice, the logic of expansionary austerity did not work out as envisaged.

A new consensus emerged amongst officialdom that the eurozone had no option but to tighten fiscal policy. At the October 2010 meeting in South Korea, the G20 FMCBG considered that substantial progress had occurred in restoring growth, and that it was now time to be concerned with fiscal overextension: 'Those countries with serious fiscal challenges [for example, Greece and Ireland] need to accelerate the pace of consolidation' (G20 FMCBG October 2010). The earlier June 2010 Toronto Summit Declaration of G20 Leaders stated that advanced economies 'have committed to fiscal plans that will at least halve deficits by 2013 and stabilize or reduce government debt-to-GDP ratios by 2016' (G20 Leaders June 2010). At this point the support in officialdom for the New Fiscalism was fracturing. A shift back to prioritizing traditional debt management to regain market confidence in the sustainability of public finances became the new leitmotiv. It was not well understood in the halls of officialdom why market confidence had evaporated only in the eurozone but not in other advanced economies with similar fundamentals and, in some instances, higher public-debt loads. Previously, the IMF had given its full support to the ramping-up of austerity measures in countries short of fiscal space:

The key task ahead is to reduce sovereign vulnerabilities ... If macroeconomic developments proceed as expected, most advanced economies should embark on fiscal consolidation in 2011. Meanwhile, given the still fragile recovery, the fiscal stimulus planned for 2010 should be fully implemented, except in economies that face large increases in risk premiums, where the urgency is greater and consolidation needs to begin now. (IMF WEO April 2010: xii, emphasis added)

What the Fund was recommending for countries without fiscal space was little different to its standard approach to balance-of-payment crises. ${ }^{6}$ The following advice to proceed

5. Expansionary austerity, as argued by a number of German and Italian economists, is the claim that fiscal consolidation - that is, fiscal austerity policies that would reduce the government deficit through higher tax rates or reduced public expenditure - ought to have an expansionary effect on the economy because of a rise in the confidence of investors. While mainstream economists often assert that nobody believes in expansionary austerity any more, Alesina et al. (2015) still argue that a reduction in government expenditure will have no negative effect on the economy.

6. For external crises, the Fund usually obligates crisis-affected countries to raise target interest rates (in order to attract financial investors); however, that option was not available for individual eurozone countries. 
cautiously with deficit reduction in the short term, while outlining credible policies to ensure a medium-term return to sound finance, was obviously directed to countries still with fiscal space:

What is essential is not so much phasing out fiscal stimulus now, but offering credible medium-term plans for debt stabilization and, eventually, debt reduction. Such credible plans may involve fiscal rules, the creation of independent fiscal agencies, and phased-in entitlement reforms. (IMF WEO October 2010: xiii-xiv, emphasis added)

The task of devising and implementing credible medium-term plans for fiscal consolidation that were also growth-friendly was emphasized time and time again in G20 communiqués during 2011 and 2012. ${ }^{7}$ G20 Leaders pledged at the June 2012 Mexico meeting to provide details on their growth-friendly fiscal retrenchment plans as part of the Los Cabos Growth and Jobs Action Plan and also launched a new accountability framework to foster compliance with commitments made. One would not usually consider pro-cyclical fiscal policy as pro-growth and pro-employment. Yet at the November 2012 G20 meeting of FMCBG in Mexico City, the 'reforms and fiscal consolidation carried out by a number of European countries' (G20 FMCBG November 2012) were identified as consistent with the Los Cabos Growth and Jobs Action Plan. At the September 2013 G20 St Petersburg Summit, the major advanced economies had detailed timetables for sustained fiscal retrenchment, and mainly rhetoric for promoting growth and jobs. That economic growth and labour market conditions were sluggish did not go entirely unnoticed. For the first time there was a meeting of the G20 Labour and Employment Ministers in Moscow in July 2012. The fracturing of the New Fiscalism was evident by G20 communiqués giving mixed messages as to whether growth and jobs would come from expansionary austerity (and front-loading fiscal austerity) or from not rushing into austerity.

Taking a longer view of history, that the embrace of the New Fiscalism did not produce robust recovery was not unexpected. In the United States, the 1930s Great Depression began with the Great Contraction of 1929-1933 and when stimulus measures were hastily withdrawn a second recession ensued in 1938. A sustained return to full employment was obtained only through the war mobilization effort. Advanced-economy policymakers in 2009, especially the eurozone, repeated the mistakes made 80 years earlier. Culpability for that failure falls heavily on European officialdom and its loyalty to anti-Keynesian ideas. The IMF also deserves criticism. While the Fund was unwilling to make a call for broad-based belt-tightening in October 2009, it did offer advice in April 2010 that most advanced economies 'should embark on fiscal consolidation in 2011', and that for the GIIPS 'consolidation needs to begin now' (IMF WEO April 2010: xii). In July 2009 the Fund published the first issue of the Fiscal Monitor which has since become a biannual accompaniment to the WEO and the Global Financial Stability Report. The preface to the May 2010 edition was written by the then IMF Managing Director, Dominique Strauss-Kahn, and included these remarks:

One of the key messages in this issue is that fiscal strategies should aim at gradually - but steadily and significantly - reducing public debt ratios, rather than just stabilizing them at their elevated postcrisis levels. Failing to do so would ultimately weaken the world's long-term growth prospects. (IMF Fiscal Monitor May 2010: 4, emphasis added)

The IMF had made the call to conclude the New Fiscalism. The title of the November 2010 Fiscal Monitor reaffirmed the new message, 'Fiscal Exit: From Strategy to Implementation'. In the July 2010 Article IV Consultation with the Euro Area, the IMF's analysis and

7. See, for example, the G20 FMCBG communiqués at the meetings in Paris in February 2011 and October 2011 and in Washington in April 2012. 
policy advice was that which neoliberal orthodoxy would repeat ad nauseam for at least the next 2 years:

The crisis was largely caused by unsustainable policies in some member countries, and has put the spotlight on the deficiency of area-wide mechanisms in disciplining fiscal and structural policies ... Immediate action is needed to establish fiscal sustainability ... Countries facing market pressures have no option but to adjust forcefully and meet their deficit targets. (IMF Euro Area Policies: Staff Report for the Article IV Consultation 2010: 1, 24, emphasis added)

In July 2011 the Fund again advised 'making fiscal consolidation a top priority' (IMF Euro Area Policies: Staff Report for the Article IV Consultation 2011: 6), and backed the region's rush to reform oriented to reinforcing fiscal discipline. Unlike European officialdom, which interpreted the crisis as caused primarily by prior fiscal laxity, the Fund considered that the lack of a fiscal union or deficient federalist fiscal architecture was also implicated in the region's crisis. ${ }^{8}$ That view echoed the analysis of Godley (1992), who presciently warned that renouncing the sovereignty to finance deficits through drafts at the central bank, while not putting in place procedures for a central government, amounted to an 'incredible lacuna' in the Maastricht programme. Nonetheless, from early 2010 to mid 2012, the IMF showed that it was not up to the task of informing global policymaking:

Earlier fears of a double-dip recession - which we did not share - have not materialized ... The policy advice to advanced economies remains largely the same ... smart fiscal consolidation that is neither too fast, which could kill growth, nor too slow, which would kill credibility ... For the recovery to be sustained, advanced economies must achieve fiscal consolidation. To do this and to maintain growth, they need to rely more on external demand. (IMF WEO April 2011: xv-xvi, emphasis added)

Here the Fund deserves stern criticism. The message the Fund needed to deliver was that fiscal consolidation would occur as a by-product of a self-sustaining recovery taking hold. Its calls for smart fiscal consolidation was fanciful Goldilocks rhetoric. The Fund failed to recognize that the weakness in private demand would persist and that as a consequence growth would be slower in advanced economies. Furthermore, the IMF forgot that one reason for its creation was to prohibit the deflationary beggar-thy-neighbour policies of the 1930s, which worsened the Great Depression. It is one thing to say that efforts in developing economies to boost domestic demand (and thereby contribute to a narrowing in external imbalances) would assist the global economic recovery and another thing to say that advanced economies should collectively rely more on external demand as an alternative to pursuing the necessary policies of domestic demand-side reflation.

At the September 2009 Pittsburgh Summit G20 Leaders requested that the IMF expand its role in bilateral and multilateral surveillance. Essentially, the multilateral consultation process which the Fund had overseen for global current-account imbalances prior to the crisis would be reinstituted, except that imbalances now explicitly meant external and fiscal. The first report of the so-called Mutual Assessment Process was delivered to G20 Leaders at the Toronto Summit June 2010. The third report delivered to G20 Leaders at the November 2011 Cannes Summit identified imbalances in seven members: China, France, Germany, India, Japan, the United Kingdom and the United States. Germany was selected for sustainability assessments on the basis of high public-debt volumes and large external surpluses. The report for Germany contained the following analysis: 'High public debt has well-known vulnerabilities associated with it ... Germany's solid fiscal position is essential for maintaining stability in the euro area' (IMF 2011: 14).

8. See, in particular, the chapter 4 discussion in the IMF Selected Issues Paper that was an accompaniment to the July 2011 Article IV Consultation with the euro area. 
That was a reiteration of the IMF's assessment in March 2010: 'the government is committed to fiscal consolidation, not least to anchor fiscal policy in the euro area' (IMF Germany: Staff Report for the Article IV Consultation 2010: 1). In July 2011 the IMF gave an analogous evaluation: 'Staff views the proposed consolidation path as appropriate ... The commitment to fiscal consolidation is strong, and the German leadership in this area carries potential medium-term benefits for Europe' (IMF Germany: Staff Report for the Article IV Consultation 2011: 26, 39).

Putting the pieces together, on the rationale that German fiscal prudence was essential to the region's stability (as well as growth prospects), the country's large external surpluses were again officially relegated to a non-issue. It is difficult to understand why the large and rapid swing in the German general government budget from -4.06 per cent of GDP in 2010 to -0.86 per cent in 2011 and +0.09 per cent in 2012 was deemed to be an appropriate pace for fiscal consolidation. As the largest economy in the eurozone, and with the European periphery short of fiscal space, there was an obligation on Germany to do more to stimulate demand in the region. And all the more so given that the country had for many years enjoyed a free ride on demand generated elsewhere.

A positive scorecard for the Fund during the New Fiscalism period from late 2008 to early 2010 became an abysmal failure. From early 2010 through to mid 2012 the IMF strongly supported the push for a New Austerity in European officialdom. In that period, not only did growth collapse and unemployment levels reach records in the eurozone (except in Germany), the region also adopted a regime of tighter fiscal governance that limits the use of counter-cyclical fiscal policy. ${ }^{9}$ At the least, it should have been obvious that the recovery would falter if the eurozone collectively sought to rapidly balance the budget. The IMF was forced to admit that the slowdown in advanced economies was 'a development we largely failed to perceive as it was happening' (IMF WEO September 2011: xiii). It also admitted to being perplexed by financial markets: 'markets appear somewhat schizophrenic - they ask for fiscal consolidation but react badly when consolidation leads to lower growth' (IMF WEO April 2012: xiv). If financial markets are schizophrenic then why should policymakers seek to accommodate their interests, which are to maximize profitability in the short run, as observed by Keynes (1936) amongst others. ${ }^{10}$ At the first sign of disquiet in bond markets the Fund along with other neoliberal orthodoxy took the view that national policymakers should be led by global finance.

\section{FAULTY ECONOMETRICS: HIGH PUBLIC DEBT HARMS GROWTH}

Econometric research played a role in the push to make fiscal austerity the number one priority. Reinhart/Rogoff s (2010) claim that there was strong evidence showing high levels of public debt were linked to low growth was widely cited. It turned out the authors had made errors (or fudged their data). Herndon et al. (2014) analysed the same data and found that the average real growth for countries with a gross public-debt-to-GDP ratio of over 90 per cent was 2.2 per cent, not -0.1 per cent. Much attention focused on the coding

9. Demand shocks are likely to be amplified as eurozone members attempt all at once to rein-in budgets to meet their debt-brake obligations that were imposed region-wide in the 2012 Fiscal Compact (Hein/Truger 2014).

10. Policymakers at the Bretton Woods Conference identified the unfettered actions of global financial markets as a cause of the Great Depression and, as a consequence, limited the role of financial markets in the postwar international monetary system. By contrast the judgement of policymakers in the Great Recession was that global financial markets were making rational assessments of public finances which had to be heeded. 
error in Reinhart/Rogoff (2010), though their analysis was misleading in other respects as well. The authors assumed that the causation ran from public debt to lower GDP growth, whereas causality could just as well be going in the other direction (Dafermos 2015). In later papers the argument was changed to: even if high volumes of public debt were caused at least partly by a financial crisis, then that does not make public debt any less dangerous.

The IMF weighed into the subject: 'there is no simple relationship between debt and growth ... [and] no single threshold for debt ratios that can delineate the "bad" from the "good"' (IMF WEO October 2012: 109). Such remarks could be read as the Fund rebuffing Reinhart/Rogoff (2010). However the chapter concluded on an ominous note: 'Italy in the 1990s suggests that debt reduction is still possible even without strong growth' (ibid.: 126). If there was a substantial policy U-turn at the Fund it had yet to filter through to the authors of the Fiscal Monitor as of April 2013:

Thanks to steady consolidation ... many advanced economies are now close to achieving primary surpluses that will allow them to stabilize their debt ratios ... [But] it is only a first step. High debt-even if stable - retards potential growth ... For all these reasons, merely stabilizing advanced economy debt at current levels would be detrimental to medium- and longer-term economic prospects. (IMF Fiscal Monitor April 2013: vii, emphasis added)

A staple of the IMF's Fiscal Monitors since July 2009 has been illustrative adjustment modelling scenarios that show the change in the primary budget balance needed to reduce the gross general government debt-to-GDP ratio to 60 per cent in advanced economies and to 40 per cent in emerging economies by 2030 (or, if the ratio is below those thresholds, then to stabilize the ratio at its current value). Intriguingly, Japan has more fiscal space than other advanced economies, with its gross public-debt target set at 200 per cent of GDP. Seemingly, in Japan's case, the IMF has implicitly taken on board one of Lerner's (1943) three claims of functional finance, that is, the claim that governments backed by a central bank faced no financial constraint. Without explanation, the October 2013 Fiscal Monitor altered its methodology:

Simulations show that maintaining the overall budget [in advanced economies] at a level consistent with the IMF staff's medium-term advice would bring the average debt ratio to about 70 percent of GDP by 2030, although in a few countries it would remain above 80 percent. (IMF Fiscal Monitor October 2013: vii, emphasis added)

Perhaps IMF staff believed that Reinhart/Rogoffs (2010) 90 per cent threshold was too high. Still, if the Stability and Growth Pact debt target was lifted by a pen stoke from 60 per cent of GDP to about 70 per cent or even above 80 per cent, then that would be a significant change. Moreover, since October 2014, the IMF no longer publishes the illustrative adjustment modelling scenarios, which is encouraging. ${ }^{11}$ Other unexpected policy advice in the October 2013 Fiscal Monitor were to repair the international tax framework (for example, crack down on corporate tax minimization and evasion); raise more revenue from the top of the income distribution; increase taxes on wealth; and adopt or increase taxes on financial transactions. ${ }^{12}$ Such policies are usually considered

11. Extrapolating the supposed effects of current fiscal policies in a neoclassical framework where the level of effective demand plays no role, and many decades into an uncertain future ( 75 years in the case of the US Congressional Budget Office), appears to have one purpose: to scaremonger on public finances. 12. Thus the tax changes advocated by the IMF were much more progressive than those advocated in 2008 by the OECD (Arnold 2008). The latter organization argued that corporate income taxes were the worst possible tax, with progressive personal income taxes a close second, while the IMF challenged both of these claims (IMF Fiscal Monitor October 2013: 31-38). 
progressive insofar as adjustment along those lines is preferable to cutting entitlements and other non-military spending.

\section{A STUNNED IMF VERSUS EUROPEAN OFFICIALDOM}

During 2012 and 2013 divergent views on macro policy advice in the ranks of neoliberal orthodoxy became more apparent in a context where economic growth was lacklustre and fading altogether in the eurozone. Amongst New Keynesians, there were those who believed that the crisis was due primarily to a liquidity trap, and that, as a corollary, fiscal multipliers were larger than normal. The policymaking implication drawn was that fiscal consolidation should be back-loaded, in the sense of being delayed until the recovery was firmly secured and the private sector had finished mending its balance sheet (Christiano et al. 2011; DeLong/Summers 2012; Eggertsson/Krugman 2012). Other New Keynesians had been pushing the case for front-loading fiscal consolidation, notably Reinhart/Rogoff (2010), as discussed in the previous section. As another example, the pioneer of New Keynesian inflation-targeting rules, John Taylor, expressed extreme scepticism about the claims of his colleagues that fiscal multipliers were now higher (Cogan et al. 2010).

There is some evidence that the IMF took a step back from its inopportune acceptance of the New Austerity from early 2010 through to mid 2012. The January 2013 IMF working paper from Oliver Blanchard and Daniel Leigh confirmed that the Fund was siding with the New Keynesians who were arguing that fiscal multipliers were significantly higher in a liquidity trap. Blanchard/Leigh's (2013) paper was a mea culpa of sorts insofar as the Fund gave an explanation for its erroneous growth forecasts. That in and of itself does not constitute a substantial U-turn in the Fund's position. What the IMF did do from mid 2013 was to more overtly urge the countries with fiscal space to do more to support growth and not just the developing countries. The Fund's renewed interest in promoting macro policies to obtain growth and jobs now also extended to the eurozone: 'The weakness of private demand [in the euro area] also suggests that countries that have scope to do so should allow automatic stabilizers to operate, and some countries with fiscal space should go even beyond this' (IMF WEO April 2013: xiv, emphasis added).

The meaning was left unclear. Was the Fund merely suggesting slowing down the pace of fiscal consolidation or even a return to discretionary fiscal stimuli as per the New Fiscalism? Inferences along those lines were made only from 2013. Importantly, from at least mid 2011, the IMF's analysis of the region's crisis and advice differed from that of Brussels (European Commission), Berlin (Merkel regime), Frankfurt (the ECB) and Basel (the Bank for International Settlements). It favoured a centralized federalist approach to resolving the crisis and also to reform, whereas European officials, especially in Berlin, were averse to any actions that would involve some mutualization of sovereign liabilities (such as the creation of a region-wide central fiscal authority with powers to issue debt and conduct macro stabilization via counter-cyclical policy). Such differences were reflected in the IMF's Article IV Consultation with the euro area in July 2011. An increase in tensions between the centre-left IMF and the centre-right Merkel regime can be discerned from around mid 2013 when it was still rather uncertain as to whether the European Monetary Union would survive the crisis as a unified bloc and it was patent to anyone but a total ideologue that the logic of expansionary austerity was failing.

IMF staff, in August 2013, recommended that 'fiscal overperformance should be firmly avoided in the current growth environment' (IMF Germany: Staff Report for the Article IV Consultation 2013: 1) and expressed concern about 'ambiguity on policies to revive growth' (ibid.: 25). In a context where the eurozone region had been in recession for 
six consecutive quarters, IMF staff were seemingly willing to consider whether 'an expeditious German fiscal stimulus could effectively boost aggregate demand in the region' (ibid.: 31). After a decade of overlooking Germany's mercantilism, the Fund was finally pressuring the country on its free-riding, as did the US Department of the Treasury (2013: 3). After previously hailing the Merkel regime's rapid fiscal consolidation as necessary to provide an anchor of regional stability in 2010 and 2011, the Fund was now arguing that fiscal austerity had gone too far, using the phrasing fiscal overperformance. Regrettably, the Merkel regime and especially its Finance Minister, Wolfgang Schäuble, have remained adamant that the eurozone crisis is due to a failure to comply with the principles of sound finance embodied in the Stability and Growth Pact. Judging from the IMF's July 2015 Article IV Consultation with Germany there is little hope for a policy change in Berlin:

[The authorities] emphasized that the current account balance is not a specific policy goal ... [They were] open to policies that might improve the corporate sector's willingness to invest in Germany and, through that avenue, reduce the current account surplus. However, they rejected any notion of fiscal stimulus citing the closed output gap and limited outward spillovers. They also emphasized that in a monetary union, monetary policy - but not fiscal policy - should be set for the union as a whole. (IMF Germany: Staff Report for the Article IV Consultation 2015: 18, 20)

Returning to the question of whether the IMF underwent a policy U-turn back towards a Keynesian orientation, there is some evidence that it did so starting from around 2013, but that the shift was inadequate. On the one hand, the Fund cautioned against excessive fiscal consolidation on the basis that fiscal multipliers were now higher, pressured the Merkel regime on its mercantilism, abandoned the modelling of illustrative adjustments and urged consideration of progressive revenue sources. On the other hand, as many if not most IMF staff still appear to accept the orthodox premise of sound finance, the difference between the Fund and European officialdom on the need for a New Austerity may be a matter of timeframe (that is, medium-term versus short-term).

\section{SECULAR STAGNATION AND A TENTATIVE NEW FISCALISM: MARK II?}

Apprehension over sluggish growth and downward revisions to potential growth were the main policy themes in 2014 and 2015. A growth target, announced in the February 2014 communiqué of FMCBG from the Sydney meeting, was reaffirmed in the November 2014 G20 Brisbane Action Plan as a 2 per cent increase in the growth path at yearend 2018 relative to the IMF's WEO October 2013 baseline scenario. Previously, in September 2014, a Global Infrastructure Initiative was launched at the FMCBG meeting in Cairns. Even the European Union signed on, pledging in November 2014 to create a European Fund for Strategic Investment. For its part, the IMF asked: 'Is it Time for an Infrastructure Push?' (IMF WEO October 2014: 75), and answered 'yes', with the usual caveats on not jeopardizing fiscal space:

Moreover, evidence from advanced economies suggests that an increase in public investment that is debt financed could have larger output effects than one that is budget neutral, with both options delivering similar declines in the public-debt-to-GDP ratio. (ibid.: 77)

The recognition that public investment is likely to be more expansionary if debtfinanced, instead of budget-neutral, was a tilt back to stimulus. That an increase in public investment can be "self-financing"' (ibid.: 78) was raised by DeLong/Summers (2012). Since April 2014 a concern with secular stagnation has appeared in every issue of the 
IMF's WEO. The October 2014 and April 2016 editions both contained modelling of a downside scenario labelled secular stagnation. Essentially, the combination of deficient demand and monetary policy constrained by the zero lower bound led to lower growth than the baseline scenario. Adding to its calls for more infrastructure spending, the Fund urged policymakers in its April 2016 editions of the WEO and Fiscal Monitor to reconsider and expand the role of fiscal policy in fostering innovation, in part by increasing expenditures on the public sector's own research and development activities and also by encouraging the same activities in the private sector (through increasing various tax credits and direct subsidies).

There is a common thread connecting public expenditures on infrastructure projects and those which foster innovative investments: both boost demand in the short run while also raising potential growth in the medium run. Similar reasoning is evident in the IMF's (WEO April 2016: 117) finding that the effects on demand and output from lowering the labour tax wedge are greater if the fiscal costs are not offset. Reducing the payroll tax could boost employment and demand in the short run, while lifting potential growth in the medium run, by reducing hysteresis. It should be noted that this in no way constitutes an endorsement of the policies of structural reforms of the labour market that were the bread and butter of the Organisation for Economic Co-operation and Development (OECD) policy advice. On the contrary, the IMF considers that reductions in unemployment benefits and job protection rules are likely to have adverse effects during periods of economic slack (WEO April 2016: 103). One could thus argue that the IMF proposals constitute a tentative New Fiscalism: Mark II, that is, qualified support for expansionary fiscal policies that boost both demand and supply. Returning to the IMF's April 2016 WEO, the logic for a scenario that would combat the effects of secular stagnation is as follows:

The fiscal response is designed both to have large short-term multipliers and to raise long-term potential output; it includes measures such as infrastructure investment, active labor market policies, and investments in research and development, as well as transfers targeted to households that would be hardest hit by a reduction in activity. It is also assumed that monetary authorities worldwide fully accommodate the fiscal response to further amplify the benefits. (IMF WEO April 2016: 31-32, emphasis added)

What the Fund now seems to be saying under the stewardship of its new Chief Economist since September 2015, Maurice Obstfeld, is that there may be sufficient fiscal space to afford growth if the central bank coordinates with the sovereign. This issue has relevance to the eurozone, where for too long there was a denial at the official level as to why the region was vulnerable to sovereign-debt crises. Current ECB President, Mario Draghi (2014), gets to the crux of the issue in his remarks that the greater fiscal space afforded to the US and Japanese governments 'reflects the fact that the central bank in those countries could act and has acted as a backstop for government funding'.

Turning to IMF staff papers, at least some of these papers reach policy conclusions which heterodox economists could agree with, but not necessarily all of the logic therein. Along these lines, Ostry et al. (2015: 18) argue that the debate over fiscal policy has so far overlooked 'simply living with (relatively) high debt, and allowing debt ratios to decline organically through output growth'. That conclusion is palatable, although the authors also claim inherited public debt 'represents a deadweight burden on the economy, dimming both its investment and growth prospects' (ibid.: 1). Perhaps any inherited debt could be cast as a deadweight for indebted agents. In an ideal world neither public debt nor private debt might exist. Debt is a systemic feature in the world that exists: 'in a dynamic growth process someone must first borrow in excess of any pre-existing amount of financial resources' (Seccareccia 2011/2012: 72). The claim that inherited 
public debt is a deadweight and that budget deficits are bad makes little sense in an economy that is interconnected through flow-of-funds accounting. ${ }^{13}$ Can budget surpluses be heralded as good if the counterpart is the private sector running deficits and building up financial vulnerabilities on its balance sheet?

In another IMF staff paper, Decressin et al. (2015) present qualified arguments querying if wage moderation will be a panacea for restoring growth, and for achieving an internal revaluation within the eurozone. ${ }^{14}$ Their main result is that the capacity of wage moderation to promote growth diminishes in tandem as more crisis-affected eurozone members pursue the policy. The authors would find that a beggar-thy-neighbour boost to net exports via wage repression could do the job, were it not for the zero lower bound constraint. What if non-crisis-affected eurozone members and the eurozone's trading partners also pursue wage moderation as has been the uniform advice of neoliberal orthodoxy for all countries since the late 1970s? Decressin et al. (ibid.: 10, fn 10) admit that their model 'cannot consider the effects of change in the income distribution on output', which is an issue that heterodox economists consider is of fundamental relevance to the subject. Again, in a footnote, Decressin et al. (ibid.: 10, fn 8) refer to a forthcoming paper (also published as an IMF working paper - see Kumhof et al. 2015) for details on another distribution channel where 'the rise in profitability, instead of spurring private investment, could spur increased lending from capital owners to workers, which increases financial fragility'. What if workers are reluctant to borrow and/or lenders are unwilling to lend because the balance sheets of workers and/or the financial sector are already financially fragile, in the terminology of Minsky (1975)?

If wage repression leads to a shift to distribution to agents with lower spending properties, and rising worker debt is not an option to offset the attending downward pressures on demand, then growth will be lower (and all the more so if fiscal policy is non-accommodating and oriented to some arbitrary budget target). In another IMF staff paper, Jaumotte/Buitron (2015) find correlations between decreasing unionization and the rise in top income shares, and between the erosion of minimum wages and overall increases in inequality. Their findings imply that if policymakers wish to address inequality, which Ostry (2015: 156) suggests they should as it 'may serve both equity and growth at the same time', then policies of wage repression will be counter-productive. And if policymakers wish to address the links between rising inequality and excessive leverage in lower- to middle-income household groups, as stressed in Kumhof et al. (2015) and which provided the spark for the Great Recession, then it may be time to consider polices conducive to wage-led growth. This is indeed the conclusion reached by Hein/Mundt (2013), who advocate a wage-led economic recovery, based in particular on the reinforcement of the bargaining power of labour unions, accompanied by what they call a Global Keynesian New Deal.

\section{CONCLUSION}

Figure 1 summarizes our view of the evolution of the fiscal policies being advocated by the IMF. Starting from an initial pro-austerity view, which had been administered to the

13. Nor do government net interest payments disappear into some accounting black hole.

14. Addressing intra-eurozone external imbalances is complicated by the fact that debtor nations cannot use currency devaluation to regain trade competitiveness with surplus countries. A Keynesian solution would contain policies to raise demand (including consumption) in the surplus countries that would thereby facilitate external balance and help realign competitiveness by generating upward pressures on wages in surplus nations. The path that the eurozone has been pursuing is antiKeynesian with the brunt of a deflationary adjustment occurring in the debtor countries through fiscal austerity and repressing wage growth. 


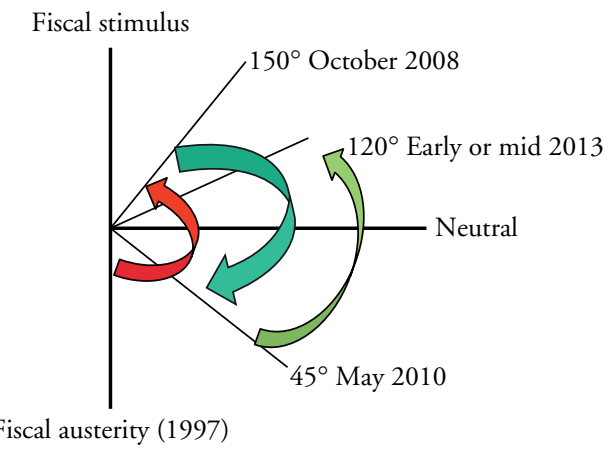

Figure 1 The partial U-turns of the IMF position

countries affected by the Asian financial crisis in 1997, the IMF moved 150 degrees towards stimulus programmes as a way to combat the recession. This occurred at the end of 2008; it was the New Fiscalism. But before the summer of 2010, the IMF reverted back towards its more traditional stance, although not completely, moving backwards by approximately 105 degrees, into a New Austerity position. Finally, sometime in 2013, the IMF moved counter-clockwise towards a more expansionary position, modifying its stance by another 75 degrees, so as to become a prudent advocate of fiscal stimulus policies, at least for the countries that were considered to have fiscal space, while other countries would be best advised to continue their austerity efforts.

Pragmatism and collective interest guided the initial policy response to the most severe global economic crisis since the 1930s. But it did not last. The fracturing of the consensus for the New Fiscalism in early 2010 was followed by a push for the New Austerity, based on the fallacy of expansionary fiscal austerity. Predictably that policy U-turn came with the cost of failing to secure a robust recovery. The parameters of debate at the official level was subsumed in the idea of smart fiscal consolidation picked up by New Keynesians and most notably by the IMF. Amongst the voices in officialdom, the Fund's performance from late 2008 to early 2010 was commendable, insofar as it led the call for a Keynesian-styled reflation. IMF staff, however, made the wrong call to advise worldwide fiscal consolidation in early 2010 and could not find any policies resembling Keynesianism to assist the GIIPS. While some sort of policy U-turn can be discerned at the Fund from around mid 2013 it was, in some respects, too little too late. Although the IMF can be criticized for not having been a more ardent advocate of fiscal stimulus policies after 2010, its New Fiscalist position was certainly better than the highly conservative perspective of European officialdom. But this is a story for another time. Whether the tentative steps towards a New Fiscalism: Mark II will be sufficient for a self-sustaining recovery remains to be seen. A question mark also remains over what officialdom will make of the efficacy of fiscal policy outside of liquidity traps/secular stagnation.

\section{REFERENCES}

Alesina, A., Favero, C., Giavazzi, F. (2015): The output effect of fiscal consolidation plans, in: Journal of International Economics, 96(supplement 1), S19-S42.

Arestis, P., Sawyer, M. (2010): The return of fiscal policy, in: Journal of Post Keynesian Economics, 32(3), $327-346$. 
Arnold, J. (2008): Do tax structures affect aggregate economic growth? Empirical evidence from a panel of OECD countries, OECD Economics Department Working Papers No 643.

Bernanke, B. (2004): The Great Moderation, Remarks at the meetings of the Eastern Economic Association, Washington, DC, 20 February.

Bernanke, B. (2007): Financial regulation and the Invisible Hand, Remarks at the New York University Law School, New York, 11 April.

Bibow, J. (2013): At the crossroads: the euro and its central bank guardian (and savior?), in: Cambridge Journal of Economics, 37(3), 609-626.

Blanchard, O. (2008): The financial crisis: initial conditions, basic mechanisms, and appropriate policies, Munich lecture, November.

Blanchard, O., Leigh, D. (2013): Growth forecast errors and fiscal multipliers, IMF Working Paper $\mathrm{WP} / 13 / 1$.

Cecchetti, S., Flores-Lagunes, A., Krause, S. (2006): Assessing the sources of changes in the volatility of real growth, NBER Working Paper No 11946.

Christiano, L., Eichenbaum, M., Rebelo, S. (2011): When is the government spending multiplier large?, in: Journal of Political Economy, 19(1), 78-121.

Cline, N., Ford, K., Vernengo, M. (2010): Because I said so: the persistence of mainstream policy advice, in: Journal of Philosophical Economics, 3(2), 97-121.

Cogan, J.F., Cwik, T., Taylor, J.B., Wieland, V. (2010): New Keynesian versus old Keynesian government spending multipliers, in: Journal of Economic Dynamics \& Control, 34(3), 281-295.

Dafermos, Y. (2015): The other half of the public debt-economic growth relationship: a note on Reinhart and Rogoff, in: European Journal of Economics and Economic Policies, 12(1), 20-28.

Decressin, J., Espinoza, R., Halikias, I., Kumhof, M., Leigh, D., Loungani, P., Medas, P., Mursula, S., Schindler, M., Spilimbergo, A., Xu, T. (2015): Wage moderation in crises: policy considerations and applications to the euro area, IMF Staff Discussion Note SDN/15/22.

DeLong, B., Summers, L.H. (2012): Fiscal policy in a depressed economy, in: Brookings Papers on Economic Activity, Spring, 233-274.

Draghi, M. (2014): Unemployment in the euro area, Speech at the annual central bank symposium in Jackson Hole, 22 August.

Eggertsson, G., Krugman, P. (2012): Debt, deleveraging, and the liquidity trap, in: The Quarterly Journal of Economics, 127(3), 1469-1513.

European Commission (2010): Reinforcing economic policy coordination, COM(2010) 250 final.

Gechert, S., Niechoj, T., Priewe, J., Watt, A. (eds) (2016): The spectre of stagnation? Europe in the world economy, in: European Journal of Economics and Economic Policies: Intervention, 13(2), $145-146$.

Godley, W. (1992): Maastricht and All That, London Review of Books, 14(19), 3-4. (Reproduced in: Lavoie, M., Zezza, G. (eds), 2012, The Stock-Flow Consistent Approach: Selected Writings of Wynne Godley, Basingstoke, UK: Palgrave Macmillan, 189-193.)

Godley, W. (2005): Why Gordon's Golden Rule is now history, in: The Guardian, 28 August, URL: www.theguardian.com/business/2005/aug/28/politics.comment.

Godley, W., Cripps, F. (1983): Macroeconomics, New York: Oxford University Press.

G20 (various years): Communiqués and Accords, URL: http://www.g20.utoronto.ca/.

Hansen, A.H. (1939): Economic progress and declining population growth, in: The American Economic Review, 29(1), 1-15.

Hein, E., Mundt, M. (2013): Financialization, the financial and economic crisis, and the requirements and potentials for wage-led recovery, in: Lavoie, M., Stockhammer, E. (eds), Wage-Led Growth: An Equitable Strategy for Economic Recovery, Basingstoke, UK: Palgrave Macmillan, 153-186.

Hein, E., Truger, A. (2014): Fiscal policy and rebalancing in the euro area: a critique of the German debt brake from a post-Keynesian perspective, in: Panoeconomicus, 61(1), 21-38.

Herndon, T., Ash, M., Pollin, R. (2014): Does high public debt consistently stifle economic growth? A critique of Reinhart and Rogoff, in: Cambridge Journal of Economics, 38(2), 254-279.

IMF (2007): The multilateral consultation on global imbalances, IMF Issues Brief, April.

IMF (2009): Global Financial Stability Report, Washington, DC: International Monetary Fund.

IMF (2011): Germany Sustainability Report: Mutual Assessment Process, Washington, DC: International Monetary Fund. 
IMF (various reports): Euro Area Policies: Staff Report for the Article IV Consultation with Member Countries.

IMF (various issues): Fiscal Monitor, Washington, DC: International Monetary Fund.

IMF (various reports): Germany: Staff Report for the Article IV Consultation.

IMF (various issues): World Economic Outlook, Washington, DC: International Monetary Fund.

Jaumotte, F., Buitron, C.O. (2015): Inequality and labor market institutions, IMF Staff Discussion Note SDN/15/14.

Keynes, J.M. (1936): The General Theory of Employment, Interest, and Money, London: Macmillan. Krugman, P. (1997): Vulgar Keynesians, URL: http://web.mit.edu/krugman/www/vulgar.html.

Kumhof, M., Rancière, R., Winant, P. (2015): Inequality, leverage and crises: the case of endogenous default, in: American Economic Review, 105(1), 1217-1245.

Lerner, A. (1943): Functional finance and the federal debt, in: Social Research, 10(1), 38-52.

Lucas, R. (2003): Macroeconomic priorities, in: American Economic Review, 93(1), 1-14.

Minsky, H.P. (1975): John Maynard Keynes, New York: Columbia University Press.

Ostry, J.D. (2015): Inequality and the duration of growth, in: European Journal of Economics and Economic Policies: Intervention, 12(2), 147-157.

Ostry, J.D., Atish, G.R., Espinoza, R. (2015): When should public debt be reduced?, IMF Staff Discussion Note SDN/15/10.

Patinkin, D. (1948): Price flexibility and full employment, in: American Economic Review, 38(4), 543-564.

Reinhart, C., Rogoff, K. (2010): Growth in a time of debt, in: American Economic Review, 100(2), 573-578.

Schäuble, W. (2010): Why Europe's monetary union faces its biggest crisis, in: Financial Times, 11 March.

Seccareccia, M. (2011/2012): The role of public investment as principal macroeconomic tool to promote long-term growth: Keynes's legacy, in: International Journal of Political Economy, 40(4), 62-82.

Seccareccia, M. (2012): Understanding fiscal policy and the New Fiscalism, in: International Journal of Political Economy, 41(2), 61-81.

Spilimbergo, A., Symansky, S., Blanchard, O., Cottarelli, C. (2008): Fiscal policy for the crisis, IMF Staff Position Note SPN/08/01, Prepared by the Fiscal Affairs and Research Departments.

Stiglitz, J. (2002): Globalisation and its Discontents, London: Penguin Books.

Summers, L.H. (2013): Remarks in honor of Stanley Fischer, Fourteenth Jacques Polak Annual Research Conference, IMF, Washington, DC, 7-8 November.

Trichet, J.-C. (2010): Interview with Jean-Claude Trichet, President of the ECB, conducted by Elena Polidori, in: La Repubblica, 16 June.

US Department of the Treasury (2013): Report to Congress on international economic and exchange rate policies, Office of International Affairs, 30 October.

Vernengo, M., Ford, K. (2014): Everything must change so that the IMF can remain the same: the World Economic Outlook and the Global Financial Stability Report, in: Development and Change, 45(5), 1193-1204.

Yellen, J.L. (2016): Macroeconomic research after the crisis, URL: https://www.federalreserve.gov/ newsevents/speech/yellen20161014a.pdf. 